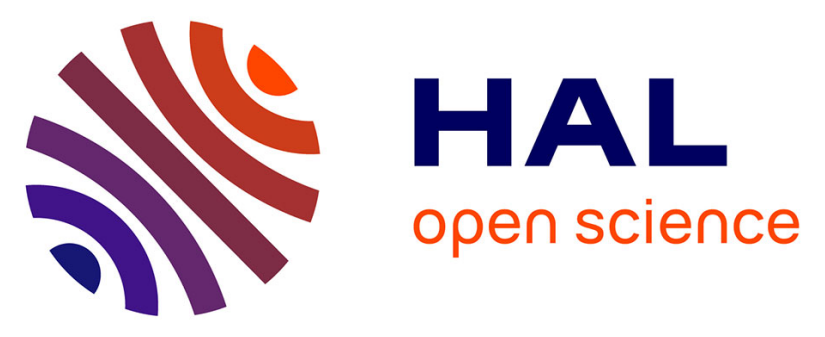

\title{
The watching-eyes phenomenon and blood donation: Does exposure to pictures of eyes increase blood donation by young adults?
}

Cécile Sénémeaud, Camille Sanrey, Nathalie Callé, Candice Plainfossé, Alexandra Belhaire, Patrice Georget

\section{To cite this version:}

Cécile Sénémeaud, Camille Sanrey, Nathalie Callé, Candice Plainfossé, Alexandra Belhaire, et al.. The watching-eyes phenomenon and blood donation: Does exposure to pictures of eyes increase blood donation by young adults?. Transfusion and Apheresis Science, 2017, 56 (2), pp.168-170. 10.1016/j.transci.2016.11.001 . hal-03261296

HAL Id: hal-03261296

https://hal-normandie-univ.archives-ouvertes.fr/hal-03261296

Submitted on 15 Jun 2021

HAL is a multi-disciplinary open access archive for the deposit and dissemination of scientific research documents, whether they are published or not. The documents may come from teaching and research institutions in France or abroad, or from public or private research centers.
L'archive ouverte pluridisciplinaire HAL, est destinée au dépôt et à la diffusion de documents scientifiques de niveau recherche, publiés ou non, émanant des établissements d'enseignement et de recherche français ou étrangers, des laboratoires publics ou privés. 
Dear author,

Please note that changes made in the online proofing system will be added to the article before publication but are not reflected in this PDF.

We also ask that this file not be used for submitting corrections. 
Short Report

\title{
The watching-eyes phenomenon and blood donation: Does exposure to pictures of eyes increase blood donation by young adults?
}

\author{
Cécile Sénémeaud ${ }^{\mathrm{a}, *}$, Camille Sanrey ${ }^{\mathrm{b}}$, Nathalie Callé ${ }^{\mathrm{c}}$, Candice Plainfossé ${ }^{\mathrm{c}}$, \\ Alexandra Belhaire ${ }^{\mathrm{d}}$, Patrice Georget ${ }^{\mathrm{d}}$ \\ a University of Caen Normandy, CERReV, EA 3918 Normandy, France \\ b University of Rennes 2, CRPCC-LAUREPS, EA 1285 Rennes, France \\ c Établissement Français du Sang Normandie, Normandy, France \\ d University of Caen Normandy, IAE of Caen - NIMEC, EA 969 Normandy, France
}

\section{A R T I C L E I N F O}

\section{Article history:}

Received 13 June 2016

Received in revised form 5 November 2016

Accepted 8 November 2016

\section{Keywords:}

Eyes image

Blood donation

Young blood donors

Prosocial

Behavior

Reputation

\begin{abstract}
A B S T R A C T
This study examined the effectiveness of exposure to a "watching-eyes image" in increasing blood donation rates among young people, a segment of the population that is particularly underrepresented among blood donors. Participants were 454 first-year university students, each of who was given a blood-donation flyer at the beginning of a lecture. Participants were randomly assigned to one of two conditions depending on whether the flyer they received bore a picture of eyes (experimental condition) or a neutral picture (control condition). We recorded the numbers of participants who promised to give blood and who actually gave blood during the blood drive. Results show that the number of people who gave blood was significantly higher in the experimental condition than in the control condition. These findings provide the first evidence of the effectiveness of the watching-eyes strategy in encouraging young people to give blood. We discuss the processes underlying the "watching-eyes effect" with respect to blood donation.
\end{abstract}

(c) 2016 Elsevier Ltd. All rights reserved.

\section{Introduction}

Young people are particularly underrepresented among blood donors in many countries, including the USA, Japan and most European countries [1,2]. For example, only $6 \%$ of French people between the ages of 18 and 24 years gave blood in 2014 (French Blood Donation Institute activity report 2014). Nevertheless, recruiting and retaining young adults, the section of the population that is in the best health for giving blood [2,3], is a major objective for blood collection agencies. The present study examined the efficacy of

\footnotetext{
* Corresponding author: Department of Psychology, University of Caen Normandy, Bat. Science E Esplanade de la Paix, 14032 CAEN Cedex, France.

E-mail address: cecile.senemeaud@unicaen.fr (C. Sénémeaud).
}

a potential new way of achieving this goal, that is, the watching-eyes social influence strategy [4].

The watching-eyes strategy involves adding a picture or pictogram of human eyes to a promotional message or object (flyer, poster, collection box, etc.) in order to influence a decision. Several recent studies have shown that this strategy can increase a wide range of prosocial and altruistic behaviors [4], including donating money to humanitarian organizations, encouraging cooperation in dictator games (i.e. economic games analyzing allocation resources between the player and another target), reducing littering and increasing voter turnout in elections [e.g. 5,6]. The traditional explanation for this effect is that the picture of eyes activates the idea of being watched, which leads individuals to behave in a more prosocial manner in order to protect or preserve their reputations [7]. 
Table 1

Percentage of participants who gave blood according to condition and pledge.

\begin{tabular}{|c|c|c|c|c|}
\hline & \multicolumn{2}{|l|}{ Condition } & \multicolumn{2}{|l|}{ Promise } \\
\hline & Control & Eyes & No pledge & Pledge \\
\hline $\begin{array}{l}\text { Percentages } \\
p \text { value }\end{array}$ & $\begin{array}{l}6.75 \%(16 / 237) \\
.002\end{array}$ & $16.12 \%(35 / 217)$ & $\begin{array}{l}2.68 \%(10 / 363) \\
<.001\end{array}$ & $50.62 \%(41 / 81)$ \\
\hline
\end{tabular}

Because western societies view blood donation as a fundamentally altruistic act [8] and because perceptions of social pressure may be an important moderating factor in blood donation, especially in the case of young adults and/or first time donors [1], we postulated that adding a picture of human eyes to a message asking people to give blood would be an effective way of persuading young adults to give blood. Our main hypothesis was that individuals who receive a flyer bearing a picture of eyes will be more likely to promise to and actually give blood than individuals who receive a flyer with a neutral picture.

\section{Materials and method}

\subsection{Participants}

Participants were 454 students (336 women and 118 men, aged around $18-19$ years). The protocol did not allow us to record and analyze participants' ages, but because they were all first-year undergraduates we can assume that the difference in the mean ages of the experimental and control groups was negligible. Participants were approached in lecture classes and randomly assigned to one of two conditions (experimental vs. control condition). In order to control for a potential effect of class, equal numbers of the two flyers were distributed in each class.

\subsection{Materials and procedure}

Participants were given a three-part blood donation flyer at the beginning of a lecture (see Appendix A). The top of the flyer bore a picture of either human eyes (experimental condition) or a neutral drawing (control condition). This was followed by the date, time and place of the blood drive. The final section of the flyer was a blood-donation pledge form through which students could promise to give blood, stating their name, date of birth and address. Students who were prepared to give blood were asked to place their pledge in the box provided at the end of the lesson. We debriefed the participants at the end of the semester, at which time we told them that we had analyzed the number of pledges made and actual donation behaviors.

\subsubsection{Dependent variables}

The first two dependent variables were the number of pledges to give blood and the number of students who actually came to the blood drive two weeks later. In order to identify participants who gave blood, an experimenter attended the blood drive in order to ask each donor (after she or he had given blood) if she or he had received a flyer two weeks before the drive and, if so, which one.

\section{Results}

We first performed multiple logistic regressions using pledge to give blood (yes vs. no) as the dichotomous criterion variable, and condition and gender as categorical predictors. Neither the effect of condition nor the effect of gender was significant, $p=.289$, and $p=.981$, respectively.

We then analyzed parameters predicting actual blood donation by carrying out multiple logistic regressions with blood donation (yes vs. no) as the dichotomous criterion variable, and gender, condition and pledge as categorical predictors. Results (see Table 1 ) showed a main effect of condition, $\operatorname{Wald}(1)=9.33, p=.002, \operatorname{Exp}(B)=3.31$ (odds ratio $[\mathrm{OR}]=2.66,95 \%$ confidence interval $[\mathrm{CI}]=1.42-4.95$ ), as the number of participants who gave blood was greater in the watching-eyes condition (35/217, i.e., $16.12 \%$ ) than in the control condition (16/237, i.e., 6.75\%). The main effect of pledge to give blood was also significant, $\operatorname{Wald}(1)=83.86$, $p<.001, \operatorname{Exp}(\mathrm{B})=40.61$ (OR, 37,21, 95\% CI, 17.32-79.92), as participants who had given a pledge were much more likely to give blood ( $41 / 81$, i.e., $50.62 \%$ ) than participants who had not given a pledge (10/373, i.e., $2.68 \%)$. Neither the gender effect nor the interaction effect was significant $(p=.873$ and $p=.995$, respectively).

\section{Discussion}

The watching-eyes strategy has been shown to increase prosocial behaviors in numerous fields, but its effectiveness has never been tested with respect to blood donation. Our study filled this research gap by analyzing the impact of the watching-eyes strategy on pledges to give blood and actual blood donations by students.

Although our results showed that the watching-eyes strategy did not impact the percentage of pledges (intentions) to give blood ${ }^{1}$, students who received a blood-drive flyer bearing a picture of human eyes were almost three times more likely to come to a university blood drive and give blood than students who received the control flyer. One possible explanation for this result is that the picture of human eyes creates a form of implicit social pressure and activates a moral obligation to donate. According to this explanation, which is consistent with the most frequently proposed interpretation of the watching-eyes effect

\footnotetext{
${ }^{1}$ This result is not surprising because it has been shown that the watching eyes effect is impacted by the presence of a large number of witnesses [5], which was the case in our study, where pledges to give blood had to be placed in a box at the front of the class.
} 
[7], seeing a pair of watching eyes triggers an avoidance motivation process through which individuals try to avoid negative judgments and thereby protect their reputations. Another possible explanation is that the picture of human eyes activates an approach motivation process, that is, it triggers a desire to help others, without regard for social rewards [9]. This explication is specific to actions such as giving blood, where helping others is one of the most important motivations. Hence, it may be that the picture of human eyes prompts people to give blood by providing a social cue in the form of another person's need for blood and by raising awareness of the usefulness of giving blood. One possible way of differentiating between these two interpretations would be to manipulate the type of social cue associated with the flyers, for example, by comparing the impact of an image showing just eyes, as in the present research, with the effect produced by an image of an entire face that is not staring toward the viewer. If the same pattern of responses were obtained, it would strongly suggest that the increased rate of blood donation produced by attaching an image of human eyes to a promotional flyer is due to the watching eyes activat-

\section{Appendix A}

Flyers illustration

Flyer bearing a picture of human eyes (Experimental condition)

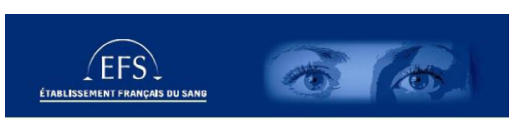

Don de sang

\section{à l'université de CAEN}

Campus 1 - salle Aula Magna

\section{References}

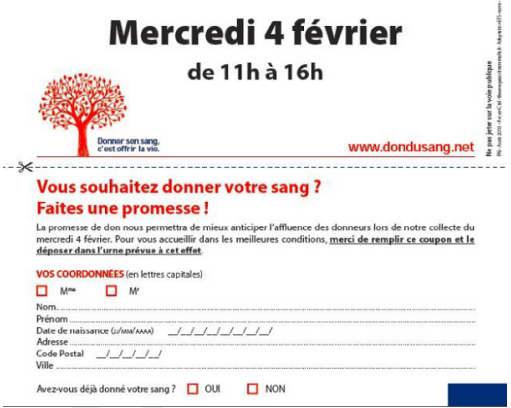

[1] Ngoma AM, Goto A, Yamazaki S, Machida M, Kanno T, Nollet K, et al. Barriers and motivators to blood donation among university students in Japan: development of a measurement tool. Vox Sang 2013;105(3):219-24. doi:10.1111/vox.12044.

[2] Lemmens KPH, Abraham C, Hoekstra T, Ruiter RA, De Kort WL, Brug J, et al. Why don't young people volunteer to give blood? An investigation of the correlates of donation intentions among young nondonors. Transfusion 2005;45(6):945-55. doi:10.1111/j.15372995.2005.04379.x. ing a desire to help others, rather than a desire to protect one's reputation.

In addition, our results support Wevers et al.'s [10] finding that first-time donors who provide a written pledge to give blood are much more likely to actually give blood. Thus, publicly signing a dated blood-donation pledge, as in our experiment, appears to create a strong commitment to give blood and increases willingness to behave consistently with the promised behavior.

Further work is required to replicate our study on a larger sample and to investigate the processes underlying the effect of the watching-eyes strategy on blood donation rates. Nevertheless, our research contributes to recent interest in the effects of watching-eyes on prosocial behaviors by showing that the watching-eyes strategy increases blood donation rates among young adults, one of the hardest age groups to recruit as regular donors.

\section{Funding and resources}

This research was supported by funding from the French Blood Donation Institute.
Flyer bearing a neutral drawing (Control condition)

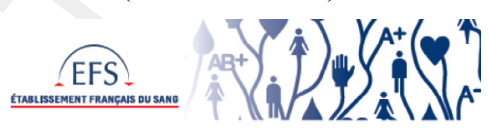

\section{Don de sang}

\section{à l'université de CAEN}

Campus 1 - salle Aula Magna

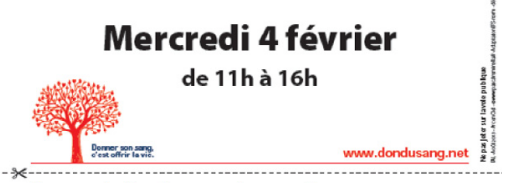

Vous souhaitez donner votre sang ?

Faltes une promesse!

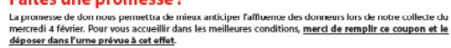

vos COOROONNEES Gen betres caprabes:

ㅁ M- $\square \mathrm{M}$

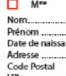

[3] Batiha AM, AlBashtawy M. Knowledge of Philadelphia University students regarding blood donation. Transfus Med. 2013;23(3):195-8. doi:10.1111/tme.12027.

[4] Bateson M, Callow L, Holmes J, Roche M, Nettle D. Do images of "Watching Eyes" induce behaviour that is more pro-social or more normative? A field experiment on littering. PLoS ONE 2013;8(12): e82055. doi:10.1371/journal.pone.0082055.

[5] Powell K, Roberts G, Nettle D. Eye images increase charitable donations: evidence from an opportunistic field experiment in a supermarket. Ethology 2012;118(11):1096-101. doi:10.1111/ eth.12011. 
[6] Panagopoulos C. Watchful eyes: implicit observability cues and voting. Evol Hum Behav 2014;35(4):279-84. doi:10.1016/j.evolhumbehav .2014.02.008.

[7] Pfattheicher S, Keller J. The watching eyes phenomenon: the role of a sense of being seen and public self-awareness. Eur J Soc Psychol 2015;45(5):560-6. doi:10.1002/ejsp.2122.

[8] Evans R, Ferguson E. Defining and measuring blood donor altruism: a theoretical approach from biology, economics and psychology. Vox Sang 2014;106(2):118-26. doi:10.1111/vox.12080.
[9] Bednall T, Bove L. Donating blood: a meta-analytic review of selfreported motivators and deterrents. Transfus Med Rev 2011;25(4):31734. doi:10.1016/j.tmrv.2011.04.005.

[10] Wevers A, Wigboldus DHJ, van den Hurk K, van Baaren R, Veldhuizen IJT. Increasing first-time blood donation of newly registered donors using implementation intentions and explicit commitment techniques. Vox Sang 2015;108(1):18-26. doi:10.1111/vox.12189. 